\title{
Catches, sales and discards: Small-scale fisheries in a Portuguese Marine park
}

\author{
Nuno Castro ${ }^{\mathrm{a}, \mathrm{b}, *}$, Filipe Romão ${ }^{\mathrm{c}}$, João J. Castro ${ }^{\mathrm{d}, \mathrm{e}}$, Tadeu José Pereira ${ }^{\mathrm{d}}$, Sílvia Pedro ${ }^{\mathrm{d}}$, \\ Vera Viegas ${ }^{\mathrm{d}}$, José Lino Costa ${ }^{\mathrm{b}, \mathrm{f}}$ \\ ${ }^{a}$ MARE - Marine and Environmental Sciences Centre, Quinta do Lorde Marina, Madeira Island, Portugal \\ ${ }^{\mathrm{b}}$ MARE - Marine and Environmental Sciences Centre, Faculdade de Ciências, Universidade de Lisboa, Portugal \\ ${ }^{\mathrm{c}}$ CERIS - Civil Engineering for Research and Innovation for Sustainability, Instituto Superior Técnico, Universidade de Lisboa, Lisboa, Portugal \\ ${ }^{\mathrm{d}}$ MARE - Marine and Environmental Sciences Centre, Universidade de Évora, Évora, Portugal \\ e Departamento de Biologia, Escola de Ciências e Tecnologia, Universidade de Évora, Portugal \\ ${ }^{\mathrm{f}}$ Departamento de Biologia Animal, Faculdade de Ciências, Universidade de Lisboa, Portugal
}

\section{A R T I C L E I N F O}

\section{Article history:}

Received 26 October 2020

Received in revised form 7 December 2020

Accepted 25 January 2021

Available online 3 February 2021

\section{Keywords:}

Marine protected areas

MPA

PNSACV

Multi-gears

Portugal

Artisanal

\begin{abstract}
A B S T R A C T
The natural park "Parque Natural do Sudoeste Alentejano e Costa Vicentina" (PNSACV; SW coast of continental Portugal) includes a recently implemented marine protected area of $2 \mathrm{~km}$ along its coast, where important, although not quantified, small-scale commercial fisheries are carried out. Conservation measures were implemented since 2011. The present study aimed to estimate the fishing effort, catches, discards and seasonality of the small commercial fleet in the northern part of PNSACV. A total of 32 fishing vessels were selected and their activity was monitored between 2011 and 2013. Fortnight interviews were made to the captains of those vessels $(n=435)$ together with on board observations $(n=89)$. The data obtained allowed to estimate a total of 100 commercial fishing vessels operating in the study area. Longlines, bottom-traps and gill/trammel nets were the most frequent fishing gears used. Over the studied period, fishing effort was more intense in the warmer season, from April to September. It was estimated that the annual fish and shellfish catches in the study area reached about $564 \mathrm{t}$, including $465 \mathrm{t}$ of sales and $99 \mathrm{t}$ of discards. Main species caught were Octopus vulgaris (65\%), Conger conger (12\%), Argyrosomus regius (2\%) and Diplodus sargus (1\%). Main species discarded were 0 . vulgaris (45\%) and C. conger (39\%), mainly due to its small size. The present pioneer work will serve as a benchmark for future studies concerning the evolution of the PNSACV and phenomena reflecting the implementation of the MPAs. Further studies should be conducted to implement legislation adjustments to improve fisheries management in PNSACV.
\end{abstract}

(C) 2021 Elsevier B.V. All rights reserved.

\section{Introduction}

Worldwide, fishing represents an activity of utmost importance, both in economic and socio-cultural terms (Pinnegar et al., 2016). The ocean has always served as a source for human nourishing and other resource extraction (Sainsbury, 1986). Throughout the years the increasing development of the fishing sector and scientific knowledge lead to new fisheries to exploit and more efficient ways of harvesting, resulting in a dramatic increase in global fishing effort (Nilson et al., 2019). The consequence was overfishing and in certain instances the collapse of some fisheries (Pauly et al., 2002; Mullon et al., 2005).

Portugal, due to its location and owning one of the largest exclusive economic zones in the world $\left(1,700,000 \mathrm{~km}^{2}\right.$, more

\footnotetext{
* Corresponding author at: MARE - Marine and Environmental Sciences Centre, Quinta do Lorde Marina, Madeira Island, Portugal.

E-mail address: Nuno.castro@mare-centre.pt (N. Castro).
}

than 18 times its terrestrial area), traditionally had a fishing sector of high importance. However, after joining the European Economic Community in 1986, its fishing sector lost some of its economic relevance due to several adopted political decisions (Baeta, 2009). In fact, in recent years the country's global catches reached half of the values recorded in 1980 (Bjørndal et al., 2015). Still, the traditional use of marine organisms in the Portuguese diet continues to be very considerable, which, together with the concentration of its population in coastal regions, makes fisheries one of the most important food sources and national livelihood nowadays as it was for several centuries (Pita and Gaspar, 2020). Portugal is one of the countries with the highest consumption of seafood worldwide and the first in Europe (DGPA, 2007; Vaz, 2008; Almeida et al., 2015). In 2018, the national fish production reached 177,685 t from fisheries and 12,549 t from aquaculture. Nevertheless, as national production meets only a part of the demand, fish imports are still required to fulfill this need, where Spain is the main source of imports (INE, 2019). 
By the end of 2018, the number of commercial fishermen registered in Portugal was 16,164 with $66.5 \%$ of the activity resulting from multi-gear fleet (using more than one fishing gear) (INE, 2019). Assigned commercial fishing licenses $(20,377)$ in that year, $84.4 \%$ were allocated to small vessels (less than $10 \mathrm{~m}$ length). These were operating using mostly multi-gears, hooks, traps or nets (INE, 2019). The majority of the captured species, in mainland Portugal (biomass), are (in descending order) Scomber colias (Gmelin, 1789), Trachurus trachurus (Linnaeus, 1758) and Sardina pilchardus (Walbaum, 1792). Purse seine followed by multi-gear fleet and bottom trawling were are responsible for the larger part of the captures (INE, 2019).

Due to the current state of exploitation of marine resources, effective and appropriate management measures must be implemented. Marine Protected Areas (MPAs) and other measures of spatial control of the fishing effort, as seasonal area closures or rotating ban areas, have been increasingly accepted as adequate tools for marine resources management and biodiversity conservation (Agardy, 1994; Murray et al., 1999; Sumaila et al., 2000; Murawski et al., 2000; Roberts et al., 2001; Jennings et al., 2009; Di Lorenzo et al., 2016; Corrales et al., 2020). MPAs are valuable tools for fisheries management, habitat protection and biodiversity, as outlined in various strategic documents, such as Code of Conduct for Responsible Fisheries (FAO, 1995) and the Green Paper on the Common Fisheries Policy of the European Union (de Vivero, 2007). Generally, MPAs management measures aim to avoid overexploitation of directed fisheries, by attempting to reduce the number and increase the age of the caught individuals of a given population. Also, by diminishing the negative impacts of fisheries on non-target species, avoiding biodiversity decrease and also the impact on fishing habitats (Gerber et al., 2003; Halpern, 2003). There are several studies suggesting that MPAs implementation generated benefits, increasing both the species abundance and specimens' average size (Bohnsack, 1993; Dugan and Davis, 1993; Halpern, 2003; Roberts and Polunin, 1991). Therefore, MPAs are relatively consensual mechanisms used to preserve the integrity of natural marine resources, helping to avoid resource overexploitation or the use of more extended fisheries management strategies (Field et al., 2006). In a recent study Di Lorenzo et al. (2020), verified that using buffering areas surrounding no take zones could enhance the spillover and fisheries. Different levels of protection or zoning are fundamental tools in MPAs management. These are subject to various uses, according to its level of protection, i.e. regulating, distinctively, various activities like fishing and tourism in certain areas that are reserved for habitat protection, nursery function or reproduction, research and education (Baptista, 2007). However, in the case of an MPA that restricts fishing areas, it is likely that this limitation leads to a decrease in the fishermen's income, in a short term ( $<5$ years) (Di Lorenzo et al., 2020) since they need to move to other fishing grounds (FAO, 2011) or find an alternative activity. For enhancing the success of MPAs implementation local populations should be directly involved (Kelleher and Kenchington, 1992). Frequently, local communities tend to oppose such management measures (Kelleher and Kenchington, 1992; Kenchington and Bleakley, 1994; Himes, 2003; Coleman et al., 2004). A valuable approach is to engage the local communities to cooperate in advice the decision making process (Sayce et al., 2013) or even in co-management (Voorberg and Van der Veer, 2020). Therefore, the management and conservation of marine resources and habitats are very complex processes that require several studies, not only about the activities of exploitation of living resources and its ecological impact, but also on the social and economic aspects (Jacquet and Pauly, 2008).

In the coast of mainland Portugal, four oceanic MPAs are in place: Litoral Norte Park (implemented in 1987, north coast),
Berlengas Natural Reserve (implemented in 1981, central coast), Arrábida Marine Park (implemented in 1998, central coast), and the Natural Park of Sudoeste Alentejano and Costa Vicentina (implemented in 1995 but designated as Marine Park in 2011, southwest coast; PNSACV). In February 2011, a new land-use plan for PNSACV was implemented. According to this document, MPAs with different protection levels (total, partial and complementary) were created. The creation of MPAs in PNSACV is relatively recent, and scientific studies on the coastal zone of PNSACV are still scarce, especially regarding biodiversity and exploitation of living resources (Castro, 2004; Pereira et al., 2017a,b,c). However, recent studies highlight that MPAs of PNSACV are effective management tools in protecting commercially important fish species (Silva, 2015; Belo et al., 2016; Pereira et al., 2017a) as well as contributing for the increment in fish size and abundance in some of those MPAs (Pereira et al., 2017b). Therefore, it is imperative to conduct further studies to examine the impact of fishing on the natural communities of PNSACV, with emphasis on the main fish stocks and discards, which are still remarkably rare (e.g. Viegas, 2013). Considering that, the general aim of the present study was to examine the commercial fishing activities in the PNSACV just after the implementation of MPAs (between 2011 and 2013) to provide a baseline for future studies, the following specific objectives were outlined: (i) to characterize the commercial fishing activity carried out on the marine area of PNSACV; (ii) to assess the fishing effort (catches, sales and discards) made by commercial fishermen, considering the fishing gear used, area of operation and time of the year.

\section{Material and methods}

\subsection{Study area}

The PNSACV was created by Regulatory Ruling $n^{0} 26 / 95$, from 21st September, and covers a wide coastal area, from São Torpes (Alentejo) to Burgau (Algarve; Fig. 1). With a total area of approximately 76,000 ha, this National Park has an extensive natural diversity, with more than a hundred sandy beaches, cliffs and dunes, as well as a marine area of $2 \mathrm{~km}$ wide and more interior land areas (ICN, 2001). The guidelines for protection and conservation of exploited fishing resources in PNSACV were initiated with the regulation of commercial barnacles harvesting in 2006 (Regulation No 385/2006, of 19 April), the most important Portuguese intertidal living resource (Cruz, 2000). In recent years, several changes occurred in the legislation. In February 2011 (Resolution No 11-B/2011), the management plan of PNSACV was reviewed and approved, and various human activities were regulated.

The study area encompasses the Alentejo area of PNSCAV, i.e., the region between the northern boundary of the PNSACV and Ribeira de Odeceixe. This includes areas of total and partial protection (Fig. 1). The total protected areas cover reefs, rocky areas and a surrounding marine band with a $100 \mathrm{~m}$ width from the maximum spring low tide, located more than $100 \mathrm{~m}$ from shore. The reefs and rocky areas of total protection are: Pedra do Burrinho; Pedra da Atalaia; the rocks adjacent to the Pessegueiro Island; Pedra da Enseada do Santoleiro and Pedra da Baía da Nau. In these areas, recreational and commercial fishing are strictly forbidden, as well as human presence. Type I partial protection includes the surrounding areas of Pessegueiro Island and Cape Sardão, where recreational and commercial fishing are forbidden, except barnacle commercial harvesting on coastal cliffs. As most fishing activities are forbidden in these partial protection areas, they are here presented as no take MPAs.

According to the Resolution No 11-B/2011, in addition to the conditions defined for the MPAs, the following activities are 


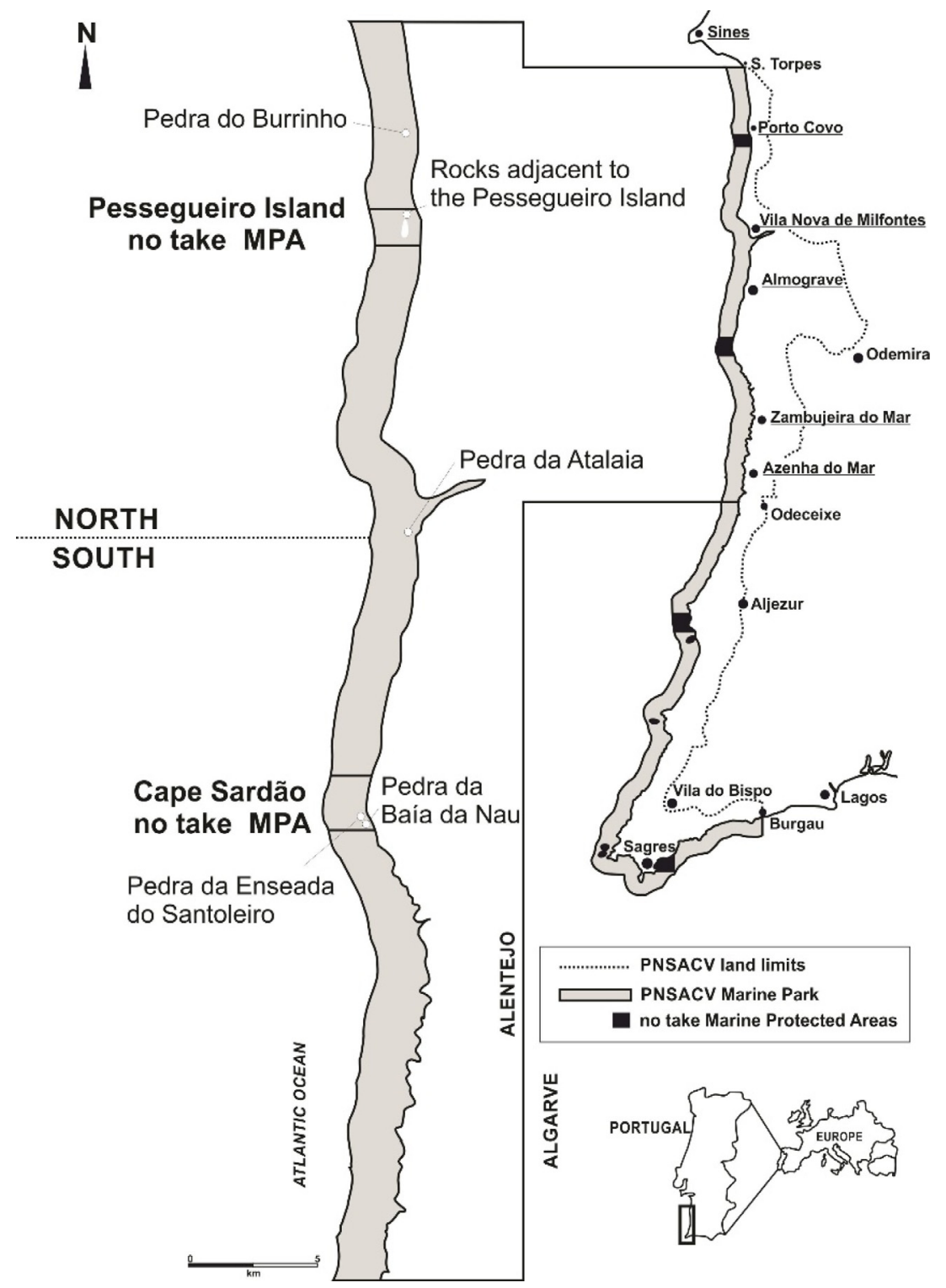

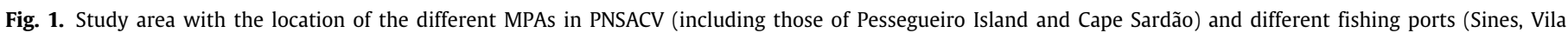
Nova de Milfontes and Zambujeira do Mar). Location of fishing ports is underlined.

also not allowed inside the PNSACV: commercial fishing trawling (dredging and bottom trawling), as well as beach seine. Moreover, commercial fishing for coastal vessels (more than $9 \mathrm{~m}$ long) is only allowed with some conditions. For example, purse seine is only permitted $\frac{1}{4}$ mile (nautical) from shore and at depths over $20 \mathrm{~m}$, while longlines are only allowed $\frac{1}{2}$ mile from shore. Up to 1 mile from the shore the normal fishing regulations are applied. On PNSACV's Alentejo coast, tourism, agriculture and fishing are the main economic activities (Castro and Cruz, 2009). Commercial fishing usually involves using vessels and exploiting subtidal environments (Castro, 2004) but also intertidal habitats (Cruz et al., 2015). The last data available from 2011 registered that the Alentejo resident population employed in fishing activities were 438 individuals (Sines Port), with a total of 239 registered fishermen in the Alentejo, most of them enrolled on multi-gear fishing (INE, 2019). The Alentejo coast of PNSACV has 6 fishing ports, namely, Sines, Porto Covo, Vila Nova de Milfontes, Lapa de Pombas (Almograve), Zambujeira do Mar and Azenha do Mar. The city of Sines holds the most important port in the region. The other ports are smaller, with less frequent use, and supporting mainly a small-scale fishing fleet (Castro, 2004). The commercial fishing fleet in the Alentejo coast was mostly represented by local vessels, small in capacity, power and size, similar to the generality of the country (INE, 2013; Pita and Gaspar, 2020).

\subsection{Preliminary screening and interviews}

In the beginning of 2011, the official statistics on the commercial fishing fleet registered in Alentejo coast (e.g. types of vessel, gear used and port of registry) were obtained from the Portuguese authority for marine resources (Direção-Geral de Recursos Naturais, Segurança e Recursos Marítimos; DGRM). This allowed to conduct a detailed identification and characterization of the potential fleet operating in the study area. Fishing captains contacts were obtained with the collaboration of the fishermen association of the Alentejo coast (Associação de Armadores da Pesca Artesanal e do Cerco do Sudoeste Alentejano e Costa Vicentina).

Interviews to fishing captains $(\mathrm{n}=78)$ were conducted in several commercial fishing ports in the study area and outside that location (Arrifana, near Alzejur; see Fig. 1). These inquiries had 
three questions: (1) verifying which vessels effectively fished in the study area (marine area of Alentejo PNSACV; Fig. 1); (2) which fishing gears were really used (despite of several licenses) in the different seasons considered, i.e. winter (less favorable sea conditions for fishing; October to March) and summer (more favorable sea conditions for fishing; April to September); (3) availability to collaborate in the study. The last question was particularly relevant since this study intended to carry out on-board observations. These interviews were carried out, in situ, and through telephone contact from September 2011 until January 2012. All interviews (preliminary and telephonic) were made with the fisherman consent, explaining first all the details of the present study. Moreover, it was explained to all the respondents that the data collected in this study would be treated anonymously and confidentiality.

\subsection{Fishing fleet and its activity in PNSACV}

The fishing fleet statistics were analyzed according to their port of registry (Sines and Sagres), vessel size [coastal vessels $(>=9 \mathrm{~m})$ and local vessels $(<9 \mathrm{~m})$ ], assigned fishing licenses (or métier) and location (northern subarea of Alentejo coast between Sines and Cape Sardão; and southern subarea - between Cape Sardão and Ribeira de Odeceixe; Fig. 1). As several vessels registered in Sagres (outside of the study area) fished in the study area, all of them were accounted in this study. The considered métiers were multi-gear (more than one fishing gear), nets (gillnets and/or trammel nets), bottom-traps (shelters and cages), lines (line and hook, rods and longlines) and purse seine. Based on the interviews, only fishing vessels that were always/sometimes used to fish in the study area were included in the study. To determine the number of vessels fishing there (always/sometimes), by gear and location, the following formula was applied:

Official number of fishing vessels in the study area

$$
=\sum_{\text {Métiers }}^{5}((P R / T R) \times \text { Official data by gear }) \text {, }
$$

where PR (positive replies) and TR (total replies) by métier (official data), $n=5$ (multi-gear, nets, bottom-traps, longlines and purse seine).

By knowing the official total number of vessels operating in the study area using multi-gears (applying the previous formula) and multiplying the relative frequency of positive responses regarding the usage of each single gear (by the multi-gear vessels), it was possible to determine the frequency of use of each gear type inside the multi-gear group:

Number of multigear vessels using a specific fishing gears

$$
=\left(\left(\frac{P R}{T R}\right) \times \text { Number of multigear vessels }\right)
$$

By summing the number of vessels using each fishing gear, determined by the previous formulas, by métier, it was possible to calculate the number of vessels operating in the study area, using each single fishing gear.

\subsection{Spatial and temporal characterization of fishing effort}

Data collected was evaluated to confirm which commercial fishing vessels were effectively operating in the study area and willingness to collaborate in the study (on-board observations and telephone surveys). A total of 24 (from a total of 81 ) vessels were selected randomly in the northern area and 8 (from a total of 19) in the southern area, according to size and gears used (Table 1). The on-board observations were proportionally stratified by (i) coastal and local fishing fleet and (ii) métier: bottom-traps, nets, longlines, purse seine and multi-gear. Since coastal vessels presented a reduced number, it was decided not to stratify the fishing fleet according to this characteristic. These fishing surveys were carried out by one or two investigators, with proper legal permits.

Telephonic interviews were conducted $(n=435)$ fortnightly to the captains of the 32 fishing vessels selected (Table 1).

Every 15 days, the information was collected regarding the number of fishing days in the study area and the gears used. The telephone calls were carried out by location (north and south subareas): 24 in the north subarea and 8 in the south subarea. The average number of fishing days by métier, location (north and south subareas) and season (cold and warm seasons) were calculated based on the telephone inquiries using the following equations ( $n=435$ ) (see Eq. (4) in Box I):

Number of fishing days of a followed vessel with a metier

in the considered period

$$
\begin{aligned}
= & \frac{\text { Number of fishing days with the specific gear }}{\text { (Total number of days in those fortnights) }} \\
& \times \text { Total number of days in those fortnights }
\end{aligned}
$$

\subsection{On-board observations}

At the same time, to retrieve information about the catches, sales and discards, in addition to the fortnightly telephone surveys, observations were carried on-board the 32 selected fishing vessels. A total of 89 on-board observations were conducted: 57 in the north subarea and 32 in the south subarea (Table 1). These were divided in the two seasons: in the north, 26 fishing trips during winter (less favorable weather and sea conditions for fishing with vessels), from October 2011 to March 2012, and 31 fishing trips during summer (more favorable weather and sea conditions for fishing with vessels), from April to September 2012; in the south, 13 fishing trips during winter, October 2012 to March 2013, and 19 fishing trips during summer, from April to September 2013 (Table 1). Ideally, both areas should be sampled in the same year, but due to operational constraints on-board observations were divided in two years. During these observations, the following information was recorded: the general characteristics of the vessel and the trip performed; time of departure and arrival; fishing gears used and its employment (number of hauls and gear(s) size); targeted species; site characteristics; number and length/weight of the captured organisms; sales and discards. The individuals captured were identified to the species level whenever possible, and their total length was registered with a precision of $0.1 \mathrm{~cm}$. Fresh weight was estimated through weight/length equations (Supplementary material 1), except in mollusks, for which the weight was recorded with a $0.1 \mathrm{~kg}$ of precision. When it was not possible to count and identify the discarded organisms on-board, they were brought to the laboratory. Once there, every individual was identified, measured $(0.1 \mathrm{~cm})$ and weighted $(0.01 \mathrm{~g})$.

\subsection{Characterization of the catches}

The information collected on-board was organized into databases, including the fishing day, the gear used, the number of captured species (also sold and discarded), as well as the location of the fishing event. Catches, sales and discards (for each species and total species) were calculated for each on-board observation. Afterwards, average daily catches, sales and discards were computed considering each gear, subarea and season reflecting all the on-board observations performed under those 
Table 1

Number of selected vessels, by métier, to perform on board observations and telephone surveys, in the two subareas (north and south) of the study area; Number of fortnightly surveys carried out between October 2011 and September 2013 to captains of fishing vessels operating in the study area, discriminated by fishing gear and subarea; Number of on-board observations made between October 2011 and September 2013 in the study area by gear, subarea and season.

\begin{tabular}{|c|c|c|c|c|c|}
\hline \multirow[t]{2}{*}{ Métiers } & & \multirow{2}{*}{$\begin{array}{l}\text { Number of } \\
\text { selected vessels }\end{array}$} & \multirow{2}{*}{$\begin{array}{l}\text { Number of } \\
\text { fortnightly } \\
\text { surveys }\end{array}$} & \multicolumn{2}{|c|}{ Number of on-board observations } \\
\hline & & & & Winter & Summer \\
\hline \multirow{4}{*}{ North } & Multi-gear & 13 & 161 & - & - \\
\hline & Longlines & 2 & 26 & 4 & 4 \\
\hline & Bottom-traps & 3 & 49 & 11 & 19 \\
\hline & Total & 24 & 297 & 26 & 31 \\
\hline \multirow{4}{*}{ South } & Multi-gear & 8 & 115 & - & - \\
\hline & Longlines & 0 & - & 2 & 6 \\
\hline & Bottom-traps & 0 & 23 & 4 & 6 \\
\hline & Purse seine & 0 & - & - & - \\
\hline \multirow{3}{*}{ Total(North and South) } & Bottom-traps & 3 & 72 & 15 & 25 \\
\hline & Purse seine & 4 & 37 & 0 & 4 \\
\hline & Nets & 2 & 24 & 18 & 11 \\
\hline
\end{tabular}

Average fishing days with a gear in the considered period

$$
=\sum \frac{\text { Number of fishing days of all vessels with a specific gear followed in the considered period }}{\text { Number of vessels followed that used that gear in the considered period }}
$$

Box I.

conditions. Subsequently, the total per gear, area and season were determined by multiplying their average values by the average number of days on which each gear was used in that season and by the number of vessels using that gear separated by north or south subareas:

Total (Catches; Sales and discards by gear, subarea and period)

= Daily average (Catches; Sales; discards on - board by subarea)

$\times$ Average number of fishing days (by gear, subarea and period)

$\times$ Number of vessels with activity (by gear, subarea and period)

To detect seasonal variations in the patterns of catches, sales and discards observed for the various fishing gears in the two subareas, a Principal Coordinate Analysis (PCO; Clarke and Warwick, 2001) was computed. This type of analysis provides a projection of sampling units arranged in a two-dimensional map, with the distances between the sampling units, (on board observations), according to their degree of dissimilarity (Clarke and Warwick, 2001). Afterwards, a one factor (season, fixed factor) PERMANOVA analysis (Anderson et al., 2008) was used to determine seasonal differences in the various métiers in the two areas, for catches, sales and discards. A main test PERMANOVA analysis was computed without restrictions of permutations of raw data, with a maximum of 999 permutations, with Monte Carlo permutation test. To assist in the interpretation of results, a homogeneity of dispersions test (PERMDISP) was applied, based on the same array of similarity (Anderson, 2006). This test analyzes the homogeneity of multivariate dispersion within each group and allows to understand the significant differences observed in PERMANOVA, which may be due to the dissimilarity between groups or dispersion variation within groups. When significant factors were detected a SIMPER test (Similarity Percentages) to assess which species mostly contribute to the similarity and dissimilarity within and between the different levels of each factor, respectively (cut-off level 90\%; only species with a percentage contribution $\geq 2 \%$ were reported; Clarke, 1993). These statistical analyses were computed with the program PRIMER \& PERMANOVA + 6 (Anderson et al., 2008). The total catches result for the PCO and PERMANOVA analysis are presented in supplementary materials (Supplementary material - Fig. 1 and Table 1), due to its similarities with sales.

\section{Results}

\subsection{Fishing activities in Alentejo coast}

According to DGRM data there were 124 registered commercial fishing vessels in Sines and 90 vessels in Sagres, in the year 2012. In both regions, there was a predominance of local fleet vessels, 79 (64\%) in Sines and 77 (86\%) in Sagres. In Sines, the average vessels length was $9.5 \mathrm{~m}$, having the smallest vessel $4.2 \mathrm{~m}$ and the biggest $26 \mathrm{~m}$. In Sagres, the average length was lower, standing in $7.8 \mathrm{~m}$, with the larger vessel reaching $25.4 \mathrm{~m}$ while the smaller had $3.8 \mathrm{~m}$. In Sines, there was a predominance of multi-gear vessels, both in coastal and local fleets. Most vessels (in both size classes) with only one license used primarily longlines as fishing gear. Also, in Sagres, a preponderance of multi-gear licenses was found for local and coastal vessels, although in this case, for those with only one license, the most common was the purse seine in larger vessels. By decomposing multi-gear in the various gears, a predominance of nets, longlines and bottom-traps was observed in Sines (Table 2). Comparatively, the scenario was relatively similar in Sagres, with a prominent role for the longlines, followed 
Table 2

Calculation of the number of licenses through fishing gear by decomposing the multi-gear fraction into its components based on equation 2 from the DGRM data of Sines and Sagres in 2012.

\begin{tabular}{|c|c|c|c|c|c|c|c|c|}
\hline \multirow[t]{3}{*}{ Métier } & \multicolumn{4}{|l|}{ Sines } & \multicolumn{4}{|l|}{ Sagres } \\
\hline & \multicolumn{2}{|c|}{$\begin{array}{l}\text { Decomposition of official data } \\
\text { (DGRM) }\end{array}$} & \multicolumn{2}{|c|}{ Study surveys } & \multicolumn{2}{|c|}{$\begin{array}{l}\text { Decomposition of official data } \\
\text { (DGRM) }\end{array}$} & \multicolumn{2}{|c|}{ Study surveys } \\
\hline & Coastal & Local & Coastal & Local & Coastal & Local & Coastal & Local \\
\hline Bottom-traps & 16 & 58 & 1 & 5 & 6 & 64 & 0 & 3 \\
\hline Longlines & 34 & 79 & 0 & 4 & 11 & 77 & 0 & 0 \\
\hline Nets & 26 & 56 & 2 & 6 & 9 & 47 & 0 & 0 \\
\hline Purse seine & 13 & 0 & 7 & 0 & 5 & 3 & 0 & 0 \\
\hline Multi-gear & 8 & 1 & 6 & 30 & 0 & 5 & 0 & 7 \\
\hline Total & 97 & 194 & 16 & 45 & 31 & 196 & 0 & 10 \\
\hline
\end{tabular}

Table 3

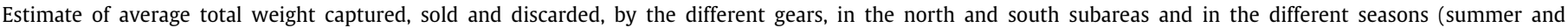
winter) (tons, fresh weight; SE - standard error).

\begin{tabular}{|c|c|c|c|c|c|c|c|c|c|c|c|}
\hline & & \multicolumn{4}{|l|}{ North } & \multicolumn{4}{|l|}{ South } & \multicolumn{2}{|l|}{ Total } \\
\hline & & Winter & $\mathrm{SE}( \pm)$ & Summer & $\mathrm{SE}( \pm)$ & Winter & $\mathrm{SE}( \pm)$ & Summer & $\mathrm{SE}( \pm)$ & Total & $\mathrm{SE}( \pm)$ \\
\hline \multirow{3}{*}{ Bottom-traps } & Captures & 123.230 & 63.470 & 309.820 & 75.750 & 3.432 & 2.970 & 18.030 & 10.580 & 454.512 & 152.770 \\
\hline & Sales & 88.100 & 50.690 & 264.920 & 58.680 & 2.978 & 2.668 & 14.258 & 8.120 & 370.256 & 120.158 \\
\hline & Discards & 35.120 & 12.780 & 44.880 & 17.070 & 0.452 & 0.301 & 3.773 & 2.461 & 84.225 & 32.612 \\
\hline \multirow{3}{*}{ Nets } & Captures & 33.475 & 27.568 & 33.335 & 25.928 & 9.684 & 7.209 & 5.886 & 3.508 & 82.380 & 64.213 \\
\hline & Sales & 29.453 & 24.253 & 29.336 & 22.569 & 8.357 & 6.043 & 4.892 & 2.668 & 72.038 & 55.533 \\
\hline & Discards & 4.021 & 3.318 & 3.998 & 3.358 & 1.327 & 1.164 & 0.995 & 0.840 & 10.341 & 8.680 \\
\hline \multirow{3}{*}{ Longlines } & Captures & 16.536 & 13.299 & 4.246 & 3.587 & 0.637 & 0.545 & 5.431 & 3.888 & 26.850 & 21.319 \\
\hline & Sales & 13.484 & 10.407 & 3.542 & 2.883 & 0.637 & 0.545 & 5.428 & 3.885 & 23.091 & 17.720 \\
\hline & Discards & 3.052 & 2.892 & 0.704 & 0.704 & 0.000 & 0.000 & 0.003 & 0.003 & 3.759 & 3.599 \\
\hline
\end{tabular}

Table 4

Results of the PERMANOVA tests performed to investigate sales and discards of the fisheries conducted in the study area between winter and summer seasons, considering different gears (bottom-traps, nets, longlines) and subareas (north, south).

\begin{tabular}{|c|c|c|c|c|c|c|c|c|c|}
\hline \multicolumn{10}{|l|}{ Sales } \\
\hline & Gears & $\mathrm{df}$ & SQ & MS & Pseudo-F & $\mathrm{P}($ perm $)$ & Unic perms & $\mathrm{P}(\mathrm{MC})$ & PERMDISP (Season) \\
\hline \multirow[t]{4}{*}{ North } & Bottom-traps & 1 & 6584.5 & 6584.5 & 74.207 & 0.001 & 999 & 0.001 & 0.011 \\
\hline & Nets & 1 & 2908 & 2908 & 0.9905 & 0.519 & 335 & 0.416 & \\
\hline & Longlines & 1 & 6679.2 & 6679.2 & 24.877 & 0.078 & 15 & 0.094 & \\
\hline & Bottom-traps & 1 & 431.83 & 431.83 & 0.20421 & 0.916 & 435 & 0.921 & \\
\hline \multirow{2}{*}{ South } & Nets & 1 & 5912.1 & 5912.1 & 19.873 & 0.012 & 562 & 0.068 & 0.616 \\
\hline & Longlines & 1 & 7315.2 & 7315.2 & 20.624 & $0.036^{*}$ & 28 & 0.119 & \\
\hline \multicolumn{10}{|c|}{ Discards } \\
\hline \multirow[t]{3}{*}{ North } & Bottom-traps & 1 & 2702.4 & 2702.4 & 18.594 & 0.126 & 997 & 0.133 & \\
\hline & Nets & 1 & 3251.9 & 3251.9 & 0.87183 & 0.619 & 277 & 0.551 & \\
\hline & Longlines & 1 & 2644.5 & 2644.5 & 0.61836 & 1.000 & 4 & 0.609 & \\
\hline \multirow[t]{3}{*}{ South } & Bottom-traps & 1 & 2049.8 & 2049.8 & 0.60074 & 0.893 & 28 & 0.679 & \\
\hline & Nets & 1 & 4342.1 & 4342.1 & 1.108 & 0.335 & 399 & 0.379 & \\
\hline & Longlines & No test & & & & & & & \\
\hline
\end{tabular}

by bottom-traps and nets (Table 2). With the completion of the interviews, it was possible to assess which métiers were used by the fishermen. It was confirmed that most of them, including in the local fleet, employed more than one gear (Table 2). However, it was also possible to determine that some gears were not used, although being registered in some fishing vessels.

\subsection{Fishing fleet and its activity in the PNSACV}

Regarding fishing activities within the study area, respondents were divided into 3 distinct groups: those who always, sometimes, and never fish in the study area (Fig. 2). Given these results, 53 captains fished in the study area at least once a year. Considering the ratio of respondents who used the study area and the DGRM official data regarding the vessels registered in the considered ports, the number of vessels effectively in activity in the study area, from October 2011 to September 2013, was calculated (100). Being the fleet operating in the north subarea, between Sines and the Cape Sardão, clearly more numerous (81) than in the south subarea (19). Subareas were dominated by multi-gear vessels, with 43 in the north and 17 in the south. More than a half of the vessels in the north operated more than one gear, and almost all the fishing vessels in the south followed the same trend. Out of the 19 vessels operating in the south, only 2 were using a single gear, while in the north this number was higher (38). By splitting the multi-gear fraction, the fishing gears used more frequently throughout the study area were longlines (64), bottom-traps (59) and nets (52), with the same happening in each subarea (Fig. 3). The data obtained from the fortnightly (telephone) inquiries (Table 1) was converted into average fishing days by gear, subarea and season. After several fishing trips, it was verified that purse seine was rarely used in the study area, being more frequent in distances beyond $2 \mathrm{~km}$ from the coast. Therefore, purse seine data was not used in the remaining analyses. In the north subarea, the average number of fishing days estimated by vessel was 97 in the winter and 139 in the summer (Fig. 4). In the south subarea, the corresponding values were 46 and 126 . Thus, the differences between subareas were higher in the winter season. 


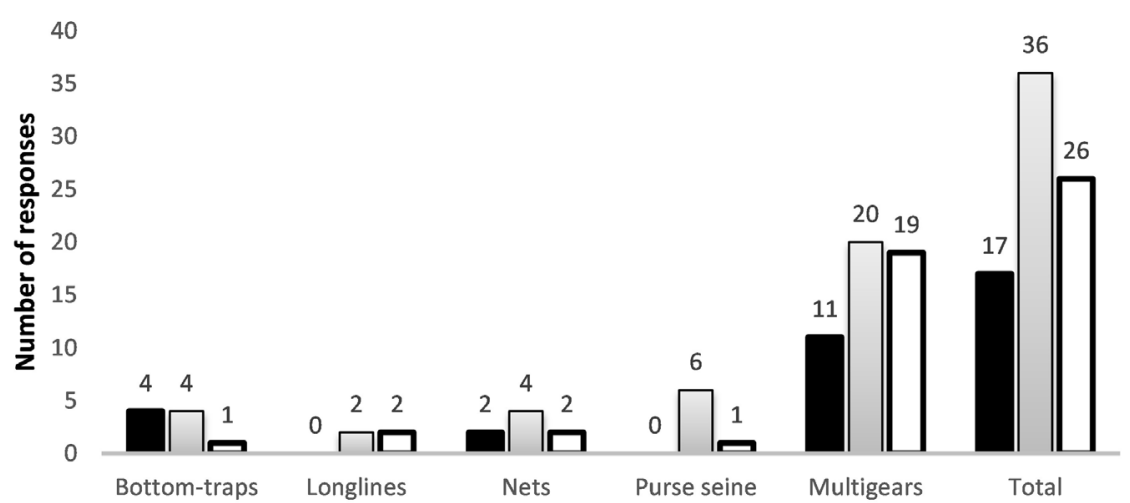

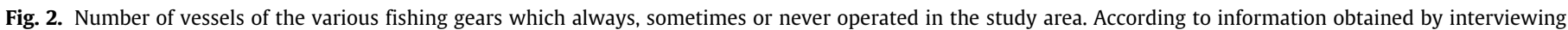
commercial fishing vessels captains from Alentejo coast ports.

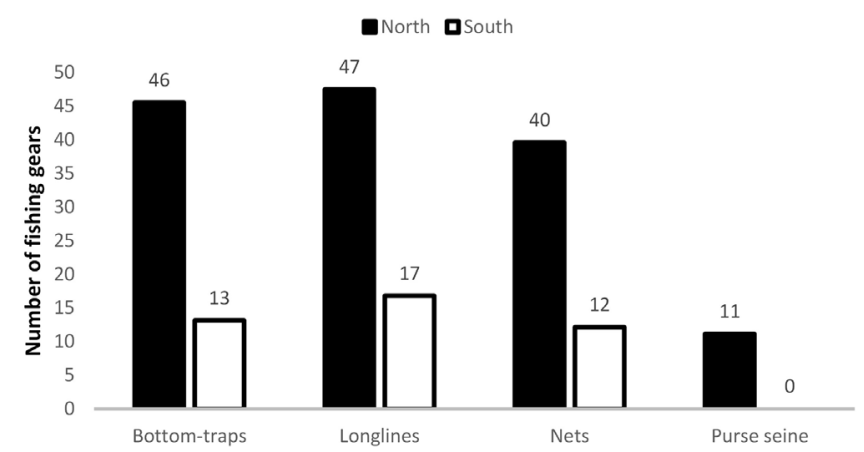

Fig. 3. Number of fishing gears operating in both subareas, north and south of Alentejo PNSACV, by the decomposition of multi-gear metiér.

\subsection{On-board observations and characterization of the chatches}

Overall, considering the whole study area, bottom-traps and nets were the gears that caught more species, while catches were more relevant in the north subarea (Table 3). In both subareas, catches were higher in summer. It was estimated that a total of $564 \mathrm{t}$ of fish and shellfish are caught annually in the study area, with $465 \mathrm{t}$ being marketed and $98 \mathrm{t}$ discarded (Table 3).

Considering the use of bottom-traps in the north subarea, a total catch of $433.1 \mathrm{t}$ was calculated (Supplementary material $2-$ Table 1), with total sales of $353.0 \mathrm{t}$ and $80.0 \mathrm{t}$ of discards (Table 3), though these indicators were higher in the summer. In total, this type of gear caught 19 species, of which 17 were sold and 14 discarded at least once (Supplementary material 2 - Table 1). The most captured and sold species were Octopus vulgaris ( $\mathrm{Cu}-$ vier, 1797) and Conger conger (Linnaeus, 1758) (Supplementary material 2 - Table 1). The PCO analysis concerning the sales from bottom-traps catches in the north subarea (Fig. 5) suggested some differentiation between seasons. Season was significant in the respective PERMANOVA analysis, as well as the PERMDISP analysis of this factor (Table 4). SIMPER analysis showed that the octopus was the dominant species in both seasons (56.81\% contribution for group dissimilarity). In the summer period octopuses sales recorded a peak, while congers were more commercialized in the winter (Supplementary material 2 - Table 1 and Table $7)$. Similar results were obtained for the total catches (Supplementary material 2 - Table 1 and Supplementary material 3). In terms of discards no significant differences were detected (Table 3 and Fig. 6), octopuses were equally discarded in the winter and summer seasons, while congers were more discarded in the summer (Supplementary material 2 - Table 1).

In the south subarea, total annual catch with bottom-traps was $21.5 \mathrm{t}$, with total sales of $17.2 \mathrm{t}$ and $4.2 \mathrm{t}$ of discards (Table 3 and Supplementary material 2 - Table 2). These estimates are quite lower compared to the north subarea. Catches, sales and discards were higher during the summer season. A total of 19 species were caught, 17 commercialized and 11 discarded, at least once (Supplementary material 2 - Table 2). Once more, the most captured and sold species were the octopus and conger. The PCO diagram did not showed any type of grouping (Fig. 5) and the respective PERMANOVA analysis confirmed the inexistence of seasonal differences (Table 4). Similar results were found for the total catches (Supplementary material $2-$ Table 2 and Supplementary material 3). Regarding the discards in bottomtraps, both in north and south subareas (Fig. 6), the PCO analysis diagrams did not suggested any seasonal differentiation. Furthermore, the results from the PERMANOVA confirmed homogeneity since no statistical differences were detected (Table 4). Sales and discards peaks were identified in the summer for octopuses and congers (Supplementary material 2 - Table 2). Overall, the most discarded species in both seasons were the octopus in the north subarea and the conger in the south subarea (Supplementary material 2 - Table 2).

In the north subarea, the nets were responsible for the capture of 66 species, 47 of which were commercialized and 46 were discarded at least once (Supplementary material 2 - Table 3). In this case, no major differences were observed between seasons by catches, sales and rejections (Table 4 ). The total annual catches were estimated to be $66.8 \mathrm{t}$, with $58.8 \mathrm{t}$ being sold and about 8.0 $\mathrm{t}$ discarded (Table 3 ). The most captured and sold species were Argyrosomus regius (Asso, 1801), Phycis phycis (Linnaeus, 1766) and Scorpaena porcus (Linnaeus, 1758), the first species mostly in winter, and the other two mainly in the summer (Supplementary material 2 - Table 3). The PCO analysis for sales (Fig. 5) did not suggested any clear grouping. The PERMANOVA analysis confirmed that no significant differences occurred between seasons with this gear in the north subarea (Table 4). Similar trends were uncovered for the total catches (Supplementary material 3). Concerning discards with nets in the north subarea, the PCO analysis (Fig. 6) again did not suggested any separation between seasons. Accordingly, the PERMANOVA revealed no significant differences (Table 4). The most discarded species were S. colias and $S$. porcus, the latter in the summer and the first in the winter (Supplementary material 2 - Table 3 ). 


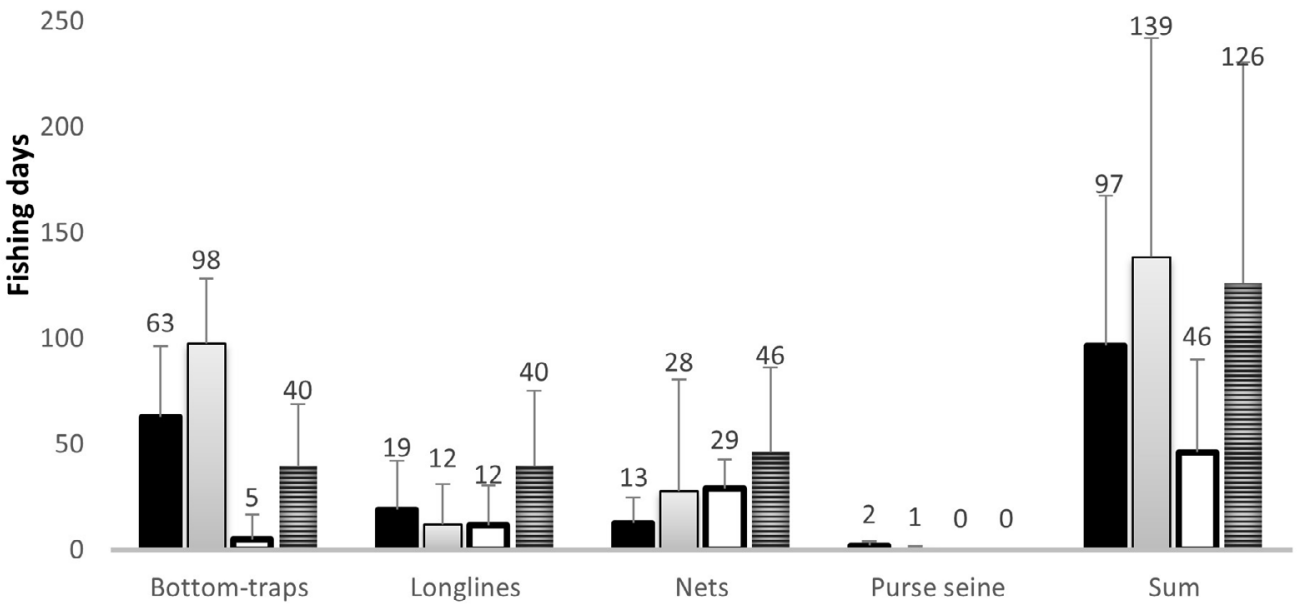

Fig. 4. Average number of fishing days, by gear, subarea and season, obtained through the fortnightly inquiries.

North Subarea

South Subarea

Bottom-traps
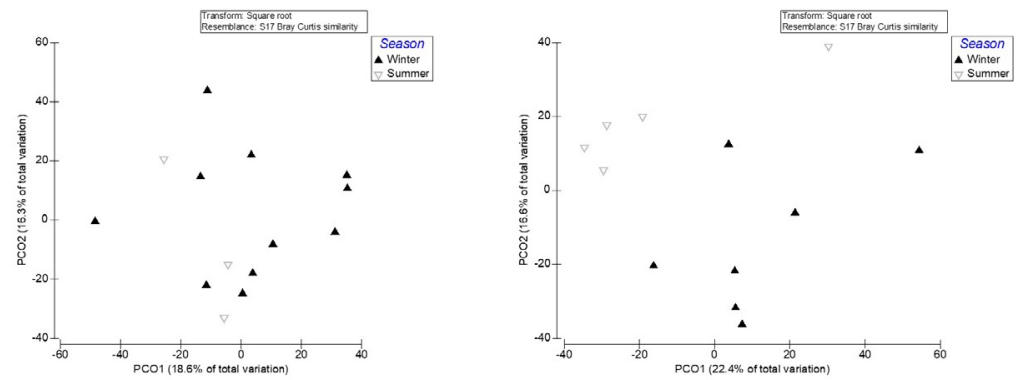

Nets
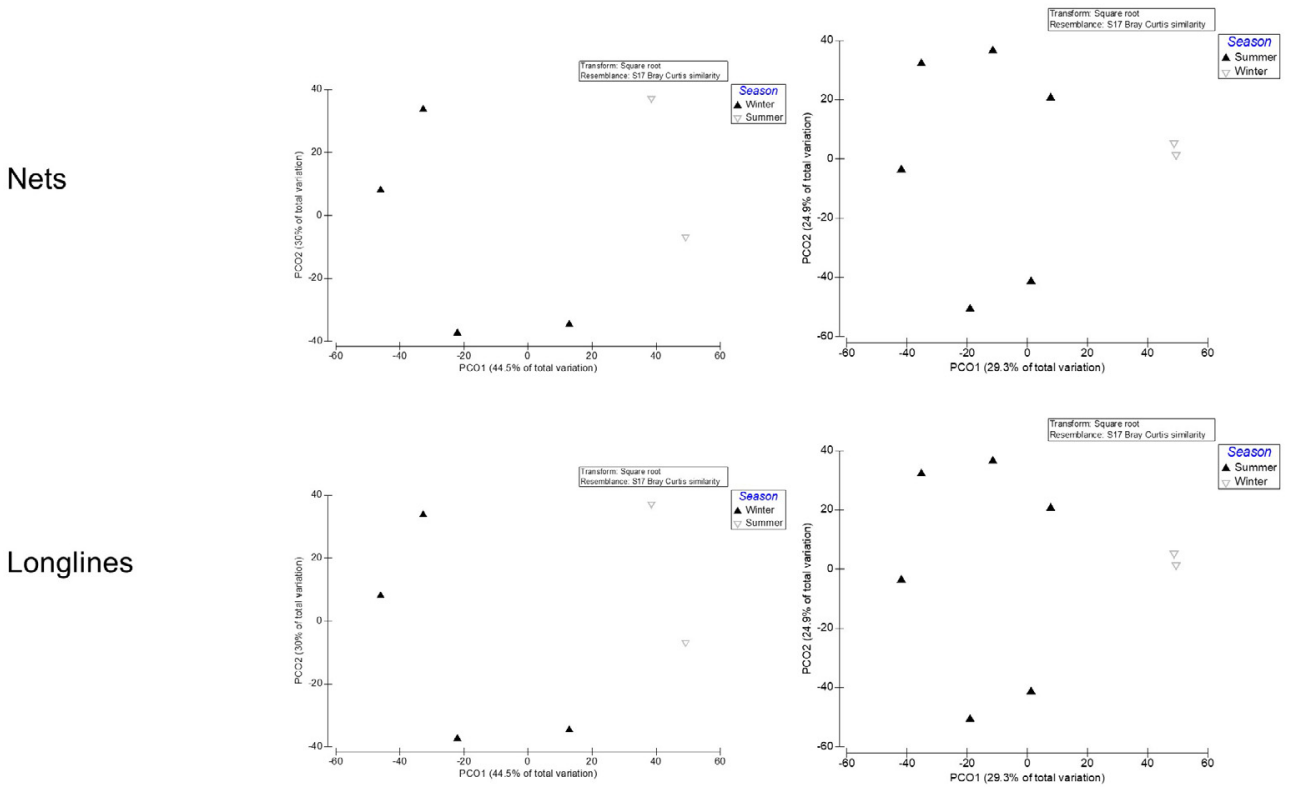

Fig. 5. Diagrams of PCO analyses performed for the sales from the fisheries in the study area with bottom-traps, nets and longlines, conducted in separate for each subarea (north, left; south, right) and considering the different seasons (summer and winter).

In the south subarea, a total of 45 species were caught, 38 species were discarded and 28 sold at least once with nets (Supplementary material 2 - Table 4 ). Nets total annual catches were estimated to be $15.6 \mathrm{t}, 13.2 \mathrm{t}$ of which were sold, and 2.3 t were discarded (Table 3). Compared to the north subarea, the 
North Subarea

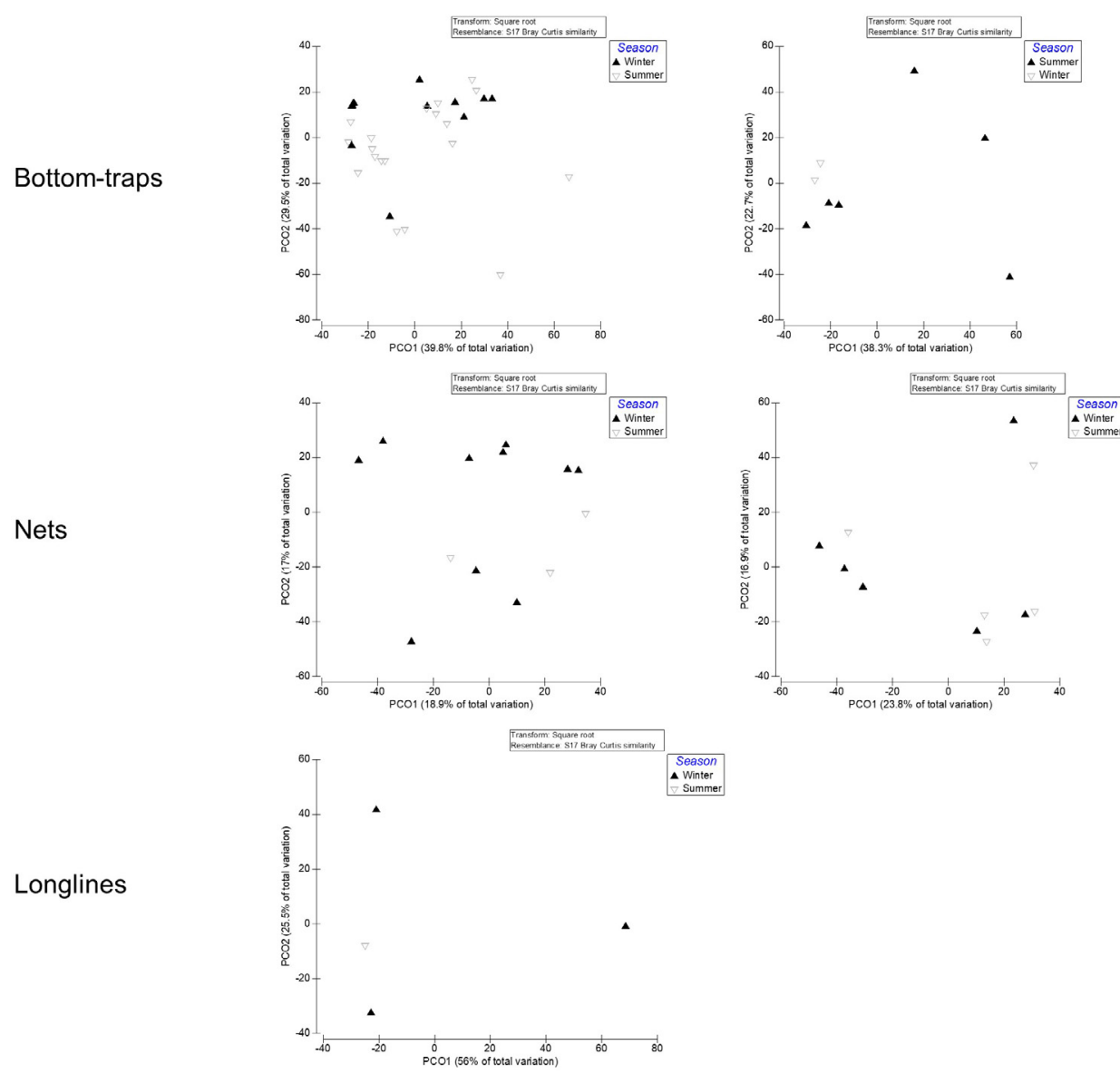

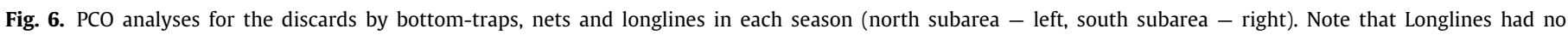
discards in the south subarea.

nets catches, sales and discards were expressively lower. In terms of species, regarding total catches and sales, it was estimated that P. phycis, Maja brachydactyla (Herbst, 1788) and Scorpaena spp. (Linnaeus, 1758), were more prominent (Supplementary material 2 - Table 3). The PCO diagram suggested two distinct clusters related to season (Fig. 5). The PERMANOVA analysis confirmed these differences (Table 4), with SIMPER verifying high average dissimilarity between seasons $(82.43 \%$ contribution for group dissimilarity) where $P$. phycis prevailed in both seasons (10.71\% contribution), Dicentrarchus labrax (Linnaeus, 1758) being predominant in the winter (8.99\%), M. brachydactyla in the summer $(7.00 \%)$, and Diplodus sargus (Linnaeus, 1758) in the winter (6.60\%) amongst other species (Supplementary material 2 - Table 8). Similar results were obtained for the total catches (Supplementary material 3). Considering the discards, Diplodus cervinus (Lowe, 1838) was the most discarded species in the summer, while the same occurred for $S$. porcus in the winter (Supplementary material 2 - Table 4). No evident seasonal separation was suggested in the PCO analysis (Fig. 6) and no differences were detected in the correspondent PERMANOVA test (Table 4).

Regarding the longlines used in the north subarea, 21 species were caught, 19 were sold and 8 discarded, at least once (Supplementary material 2 - Table 5). In terms of fish caught annually, a total of $20.8 \mathrm{t}$ was estimated, $17.0 \mathrm{t}$ of which were sold, and the remaining $3.8 \mathrm{t}$ discarded (Table 3 ). The most captured and sold species were $D$. sargus and $P$. phycis, the first in the winter and the second in both seasons. Conger and Serranus cabrilla (Linnaeus, 1758) were the most discarded species, mostly in the winter (Supplementary material 2 - Table 5). Contrary to what was observed in other gears/subareas, longlines had more catches, sales and discards in the winter (Supplementary material $2-$ Table 5). In the south subarea, the longlines total annual catches were around $6.1 \mathrm{t}$, almost entirely destined for commercialization due to reduced discards (Table 3 and Supplementary material 2 - Table 6). In total, 17 species were captured, all were sold and only 1 species was discarded, at least once (Supplementary material 2 - Table 6 ). The most captured and sold species were Pagrus pagrus (Linnaeus, 1758) and conger, respectively. The only discarded species was Boops boops (Linnaeus, 1758) (Supplementary material 2 - Table 6). The PCO for the longlines analyses both in the north and in the south subareas (Fig. 6) suggested some dissociation between seasons, but the respective PERMANOVA analyses did not confirm those differences (Table 4). Conversely to what happened in the north subarea, southern catches and sales occurred mainly in the summer. Similar results were obtained for the total catches (Supplementary material 3). Considering the longlines discards, the PCO analysis and PERMANOVA test were only conducted for the north subarea, because there were several fishing days with no discards in the south. In the correspondent PCO diagram no segmentation regarding 
seasons was suggested (Fig. 6) and no statistical differences were observed either in the correspondent PERMANOVA test (Table 4).

\section{Discussion}

The present study estimated the total catch of $564 \mathrm{t}$ of fish and shellfish from the PNSACV marine area. This represents a large difference compared with the official landings data (INE, 2013). The official numbers for Sines (encompassing all the fishing harbors in the region of Alentejo) in 2011 and 2012 were 9,410 t and $8,442 \mathrm{t}$, respectively. It is likely that this variation occurred because the present study targeted only the fishing activity in the PNSACV, where fishing is carried out mainly by local vessels, resulting in less fishing effort and for this reason, significant fewer catches. While coastal vessels can exploit other habitats and are not restricted to the boundaries of the PNSACV.

Fishing in the Alentejo coast is a very old tradition, that passed from parents to children, being one of the main sources of income for many local families (Castro, 2004; Castro and Cruz, 2009). Fishing vessels from the north subarea, mainly moored in the port of Sines, were have more favorable conditions, in terms of sheltered waters and harbor conditions (Castro, 2004). In fact, the port of Sines, besides having a fishing harbor inside, it is also an open deep-water seaport that handles and receives any type of vessel and cargo (www.portodesines.pt). These facilities allow fishing vessels to leave the port even with harsh sea conditions, which contributes to a greater fishing effort, resulting in a greater quantity of specimens caught and sold. In the south subarea, only small ports exist, poorly intervened, with more difficult access and where larger vessels cannot enter and dock (Brejo, 1988). These small ports are subjected to the harsh hydrodynamic conditions experienced in the region, particularly in the winter (Pereira et al., 2017c). Thus, as many fishing operations are dependent on the tide, sea and weather conditions, the seasonality factor plays a greater effect in the south subarea, which contributes to a reduced fishing effort in the area, particularly in the winter. The number of fishermen registered in the region correspond to only $1.7 \%$ of the total for mainland Portugal (INE, 2019), despite the extension of the study area. The number of fishing vessels operating in the study area is relatively lower (100 vessels) compared to Arrábida Marine Park (PNA) where more than 150 fishing vessels operate in that region (Baptista et al., 2009). The PNA has around $53 \mathrm{~km}^{2}$ of marine protected area whereas the PNSACV has almost four times that in all its extent (www.icnf.pt). Most regional fishing vessels use a wide variety of fishing gears, a situation also found in locations areas in the southwestern coast (Baptista, 2007) and, generally, in Portugal (INE, 2019; Pita and Gaspar, 2020). This gear heterogeneity allows fishermen to explore diverse habitats and capture different species.

The most captured species in the PNSACV, according to the biomass (annual catch; fresh weight) estimated in this study, were the octopus $(365.8 \mathrm{t})$, conger $(66.0 \mathrm{t})$ and the meagre $A$. regius (11.14 $\mathrm{t}$ ). According to government statistics, in 2012, all these species had higher landed values, but moderately close to our estimates (INE, 2013). Regarding official numbers, in 2012, $451.2 \mathrm{t}$ of octopus landed in Alentejo (INE, 2019). The octopus has a distribution from the coastline to the edge of the continental shelf (Roper et al., 1984). In a work carried out in the MPA of the Arrábida Natural Park (PNA), octopuses were caught from the coastline up to $200 \mathrm{~m}$ away, and larger specimens were fished further from the coast (Alves, 2008). According to Lourenço and Pereira (2006), the octopus has high economic value and is a highly ranked species in Portuguese ports. In 2012, $76.9 \mathrm{t}$ of conger were landed in Alentejo (INE, 2013). The conger has a distribution from the shoreline to $500 \mathrm{~m}$ from shore and can reach up to $3 \mathrm{~m}$ (total length) and $110 \mathrm{~kg}$ (Muus et al., 1999;
Smith, 1990). This species takes refuge in rocks, leaving at night to feed (Pita and Freire, 2011; Pereira et al., 2017c). The meagre uses estuaries to spawn, and in Portugal the Tagus, Mira (near the study area) and Guadiana estuaries are known habitats for this species (Costa, 2004; Prista et al., 2008). According to some authors, there is a marked seasonal variation in this species landings linked to juvenile and adult migrations identified in local fisheries (Quéro and Vayne, 1987; Prista et al., 2008). In fact, this was observed in present study, as the catches of this species were only relevant in the winter in the north subarea, near the Mira estuary (Vila Nova de Milfontes) indicating a likely spawning migration to the estuary. The official landing number for this species is $14.5 \mathrm{t}$ in Alentejo (INE, 2013), tightly close to this study estimates.

In terms of discards, a total of $99 \mathrm{t}$ of fish and shellfish were estimated to be rejected throughout the marine area of the PNSACV, which corresponds to $16.1 \%$ of the total captured. According to the official statistics, $35 \mathrm{t}$ of catches fish are discarded in the Alentejo area (INE, 2019), but due to the impossibility of being sold. This last number is considerably lower compared to the present study data (within the limits of the PNSACV). During this study, it was possible to determine the reasons towards species rejection, namely the low commercial value, size/weight of the organism below the legal limit and specimen damaged/improper for sale (or consumption). Most discards focused on the octopus and conger, that were mostly captured with bottom-traps (86\%). This gear aims to catch octopus, a traditional fishery in local communities, but bottom-traps are also used to catch conger and other marine species (Cunha and Moreno, 1994). Being a very selective gear, its discards are mainly composed of octopuses and congers. Indeed, this gear, like the name suggests, aims to capture and retain the specimen, keeping them alive, leading to "alive" discards which represents a much lower impact, compared to other gears. However, it is worth considering that this gear has a higher percentage of discards. In this study, most discarded octopuses were due to low weight. The lower limit for the octopus commercialization is 750 grams. Alves (2008), when studying fisheries in PNA, found that $14 \%$ of the captured octopus were discarded because they were below the minimum weight allowed by law, whereas the conger in the present study was largely discarded due to its low commercial value in reduced sizes.

Nets were the second gear with more organisms discarded (10.5\%), with differences in species composition between areas. In the north subarea, discards were of $S$. colias and Scorpaena spp., which were damaged and/or unfit for sale or consumption. Correspondingly, in the south subarea, the discarded species were $D$. cervinus and $P$. phycis, for the same reasons. Borges et al. (2001) found a similar percentage of discards (13\%) when studying fisheries in the south of mainland Portugal. Nets are less selective, capturing a greater diversity of species, hence causing a higher impact on fish communities, as several other studies described (Hamley, 1975; He, 2006; Shester and Micheli, 2011). In the present study, this percentage of discards was due to the immersion time of the nets (soak time), especially in the south subarea, soak time was often more than $24 \mathrm{~h}$, because fishing vessels often could not leave the harbors due to harsh weather and/or sea conditions. Other authors (Alves, 2008; Baptista et al., 2009; Erzini et al., 2001) found that the nets soak time was a key factor linked to the high discards rate, due to the specimen's degradation as a consequence of environmental factors (e.g. hydrodynamics), but also biological factors (e.g. predators; Alves, 2008).

In the north subarea, the longline discards were characterized by small individuals (e.g. small congers) that have low commercial value, while in the south subarea they were almost null. Erzini et al. (1999) summed up this type of gear as a métier that does not produce intensive negative ecological effects in the 
environment, with reduced catches of fish below legal size, low rejection rates and high-quality fish.

In terms of species catches, seasonality was only evident with bottom-traps (north subarea) and nets (south subarea). The bottom-traps significant differences were probably due to the dispersion within the winter and summer groups and not to the dissimilarity between them. As previously referred, the summer period allows more intense fishing, with subsequent differences in the number of octopus caught in this period in the north subarea and/or this seasonal difference in landings could be probably related to reproductive strategies (Baptista et al., 2009). Looking at south subarea and nets, the seasonal differences were mainly due to the sea bass ( $D$. labrax) and meagre high abundance in winter compared to summer. The sea bass and the meagre hold a high commercial value and both use estuaries and ocean areas (Whitehead et al., 1989; FAO, 2010). These species are found in coastal areas, however, due to their migratory behavior, they search for deeper waters during the winter (Pickett and Pawson, 1994; Prista et al., 2008). The Mira estuary serves as seasonal refuge for these species, which leave this system to explore the coastal areas of PNSACV. Costa (2004) verified that the income of coastal fisheries had a peak in late summer, due to the abandonment of the Mira estuary in that period by some fish species.

The data obtained in the present work provided a baseline for the catches, sales and discards of the commercial fishing fleet operating in the Alentejo coast of the PNSACV just after the marine park implementation in 2011. Thus, this work establishes a reference condition for future studies concerning the evolution of the marine park and its halieutic resources and phenomena like spillover that can be reflected in the revenues of the regional fishing fleet. Based on the obtained results, we recommend further research activities. Future studies should address the impact of these fisheries in sensitive and protected species (e.g. Epinephelus marginatus). An assessment of the evolution of the socio-economic status of the local fishing communities after the MPA implementation should be conducted towards detect positive and negative impacts and allow corrective measures, if necessary. A more detailed study on the usage of nets in the study area is urgent, since this type of gear leads to high discards and consequent fish mortality.

\section{CRediT authorship contribution statement}

Nuno Castro: Conceptualization, Methods and data collection, Analyses and visualization, Writing. Filipe Romão: Methods and data collection, Writing. João J. Castro: Funding acquisition, Resources, Writing. Tadeu José Pereira: Methods and Data Collection, Writing. Sílvia Pedro: Methods and data collection, Writing. Vera Viegas: Methods and data collection, Analyses and visualization, Writing. José Lino Costa: Conceptualization, Funding acquisition, Resources, Supervision, Writing.

\section{Declaration of competing interest}

The authors declare that they have no known competing financial interests or personal relationships that could have appeared to influence the work reported in this paper.

\section{Acknowledgments}

The authors gratefully thank to all the fishermen that cooperated in the present study, also to Capitania do Porto de Sines, and Associação de Armadores de Pesca Artesanal e Cerco do Sudoeste Alentejano e Costa Vicentina (AAPACSACV). We further acknowledge Direção-Geral de Recursos Naturais, Segurança e
Serviços Marítimos (DGRM) and Nuno Prista and Alexandra Silva. Also thank the colleagues António Fernandes, André Costa, Maria João Tavares and Nélia Penteado. The present work was funded by the University of Évora, Portugal through the project 'Estudos científicos para proteção marinha na costa alentejana - PROTECT' and co-funded by the European Fisheries Fund 2007-2013 (EFF) through the Portuguese Fisheries Operational Program (PROMAR) 2007-2013 (operation: 31-03-05-FEP-12). Additionally, this work was financially supported by FEDER, Portugal by means of 'Programa Operacional Fatores de Competitividade - COMPETE' and National Funds, Portugal through FCT - Foundation for Science and Technology via the strategic project UIDB/04292/2020 and SFRH/BD/146881/2019 (Doctoral awarded to Nuno Castro).

\section{Appendix A. Supplementary data}

Supplementary material related to this article can be found online at https://doi.org/10.1016/j.rsma.2021.101643.

\section{References}

Agardy, M.T., 1994. Advances in marine conservation: the role of marine protected areas. Trends Ecol. Evol. 9, 267-270.

Almeida, C., Karadzic, V., Vaz, S., 2015. The seafood market in Portugal: Driving forces and conseques. Mar. Policy 61, 87-94. http://dx.doi.org/10.1016/j. marpol.2015.07.012.

Alves, A., 2008. Catch and By-Catch of Artisanal Fisheries in the ArráBida Marine Protected Area (Portugal) (MSc thesis). University of Lisbon, Lisbon.

Anderson, M.J., 2006. Distance-based tests for homogeneity of multivariate dispersions. Biometrics 62, 245-253.

Anderson, M.J., Gorley, R.N., Clarke, K.R., 2008. PERMANOVA+ for PRIMER: Guide to Software and Statistical Methods. PRIMER-E, Plymouth, UK.

Baeta, A., 2009. Environmental Impact and Sustainability of Portuguese Fisheries (Ph.D. thesis). University of Lisbon, Lisbon.

Baptista, M., 2007. Avaliação do impacto do Plano de Ordenamento da Área Marinha do Parque Natural da Arrábida na pesca comercial local (MSc dissertation). University of Lisbon, Lisbon.

Baptista, M.I., Teixeira, C.M., Cabral, H.N., 2009. Catches of target species and bycatches of an artisanal fishery: the case study of a trammel net fishery in the portuguese coast. Fish. Res. 100, 167-177.

Belo, A.F., Pereira, T.J., Quintella, B.R., Castro, N., Costa, J.J., Almeida, P.R., 2016. Movements of Diplodus sargus (Sparidae) within a Portuguese coastal marine protected area: are they protected? Mar. Environ. Res. 114, 80-94.

Bjørndal, T., Lappo, A., Ramos, J., 2015. An economic analysis of the Portuguese fisheries sector 1960-2011. Mar. Policy 51, 21-30.

Bohnsack, J.A., 1993. Marine reserves: they enhance fisheries, reduce conflicts, and protect resources. Oceanus 36, 63-71.

Borges, T.C., Erzini, K., Bentes, L., Costa, M.E., Gonçalves, J.M.S., Lino, P.G., Pais Ribeiro, J., 2001. By-catch and discarding practices in five Algarve (southern Portugal) métiers. J. Appl. Ichthyol. 17, 104-114.

Brejo, J., 1988. A pesca no litoral alentejano. In: Comissão de Coordenação da Região do Alentejo.

Castro, J.J., 2004. Predação Humana No Litoral Rochoso Alentejano: Caracterização, Impacte Ecológico e Conservação (Ph.D. thesis). University of Évora, Évora.

Castro, J.J., Cruz, T., 2009. Marine conservation in a SW Portuguese natural park. J. Coast. Res. 385-389, Proceedings of the 10th International Coastal Symposium.

Clarke, K.R., 1993. Non-parametric multivariate analyses of changes in community structure. Aust. J. Ecol. 18, 117-143. http://dx.doi.org/10.1111/j. 14429993.1993.tb00438.x.

Clarke, K.R., Warwick, R.M., 2001. Change in Marine Communities: An Approach to Statistical Analysis and Interpretation, second ed. PRIMER-E, Plymouth, UK.

Coleman, F.C., Figueira, W.F., Ueland, J.S., Crowder, L.B., 2004. The impact of United States recreational Fisheries on marine fish populations. Science 305, 1958-1960.

Corrales, X., Vilas, D., Piroddi, C., Steenbeek, J., Claudet, J., Lloret, L., Calò, A., Di Franco, A., Font, T., Ligas, A., Prato, G., Sahyoun, R., Sartor, P., Guidetti, P., Coll, M., 2020. Multi-zone marine protected areas: Assessment of ecosystem and fisheries benefits using multiple ecosystem models. Ocean Coast. Manag. 193, 105232. http://dx.doi.org/10.1016/j.ocecoaman.2020.105232.

Costa, J.L., 2004. A biologia do xarroco, Halobatrachus didactylus (Bloch \& Schneider, 1801), e o seu papel na estruturação e funcionamento das comunidades em que se insere; referência especial à população do Estuário do Mira (Ph.D. thesis). University of Lisbon, Lisbon, p. 925. 
Cruz, T., 2000. Biologia e ecologia do percebe, Pollicipes pollicipes (Gmelin, 1790), no litoral sudoeste Português (Ph.D. thesis). University of Évora, Évora.

Cruz, T., Jacinto, D., Sousa, A., Penteado, N., Pereira, D., Fernandes, J.N., Silva, T., Castro, J.J., 2015. The state of the fishery, conservation and management of the stalked barnacle Pollicipes pollicipes in Portugal. Mar. Environ. Res. 112, 73-80. http://dx.doi.org/10.1016/j.marenvres.2015.10.005.

Cunha, M.M., Moreno, A., 1994. Octopus Vulgaris: Its Potential on the Portuguese Coast. International Council for the Exploration of the Sea, Vol. 33, p. 19, (CM Papers and Reports), CM 1994/k.

DGPA, 2007. Plano estratégico para a pesca 2007-2013. Direção-Geral de Pescas e Aquicultura.

Di Lorenzo, M., Claudet, J., Guidetti, P., 2016. Spillover from marine protected areas to adjacent fisheries has an ecological and a fishery component. J. Nat. Conserv. 32, 62-66. http://dx.doi.org/10.1016/j.jnc.2016.04.004.

Di Lorenzo, M., Guidetti, P., Di Franco, A., Calò, A., Claudet, J., 2020. Assessing spillover from marine protected areas and its drivers: A meta-analytical approach. Fish Fish. 21, 906-915. http://dx.doi.org/10.1111/faf.12469.

Dugan, J.E., Davis, G.E., 1993. Applications of marine refugia to coastal Fisheries management. Can. J. Fish. Aquatic Sci. 50, 2029-2042.

Erzini, K., Gonçalves, J.M.S., Bentes, L., Lino, P.G., Ribeiro, J., 1999. Catch composition, catch rates and size selectivity of three long-line methods in the Algarve (southern Portugal). Bol. Inst. Esp. Oceanogr. 15, 313-323.

Erzini, K., Gonçalves, J.M.S., Bentes, L., Lino, P.G., Ribeiro, J., 2001. The hake deepwater semi-pelagic (pedra-bola) longline fishery in the Algarve (southern Portugal). Fish. Res. 51, 327-336.

FAO, 1995. Code of Conduct for Responsible Fisheries. Rome, Italy, p. 41.

FAO, 2010. Synthesis of the Mediterranean marine finfish aquaculture-A marketing and promotion strategy. In: Studies and Reviews. General Fisheries Commission for the Mediterranean, no. 88, FAO, Rome, Italy, pp. 1-221.

FAO, 2011. Fisheries management. 4. Marine protected areas and fisheries. In: FAO Technical Guidelines for Responsible Fisheries, No. 4, Suppl. 4. Rome. p. 198.

Field, J.C., André, E.P., Methot, R.D., Thomson, C.J., 2006. Does MPA mean 'Major Problem for Assessments'? Considering the consequences of place-based management systems. Fish Fish. 7, 284-302.

Gerber, L.R., Botsford, L.W., Hastings, A., 2003. Population models for marine reserve design: a retrospective and prospective synthesis. Ecol. Appl. 12, 47-64.

Halpern, B.S., 2003. The impact of marine reserves: do reserves work and does reserve size matter? Ecol. Appl. 12, 117-137.

Hamley, J.M., 1975. Review of gillnet selectivity. J. Fish. Board Can. 32 (11), 1943-1969.

He, P., 2006. Gillnets: gear design, fishing performance and conservation challenges. Mar. Technol. Soc. J. 40 (3), 12-19.

Himes, A.H., 2003. Small-scale sicilian Fisheries: Opinions of artisanal Fishers and sociocultural effects in two MPA case studies. Coast. Manag. 31, 389-408.

ICN, 2001. Turismo de Natureza: Enquadramento Estratégico, Parque Natural Do Sudoeste Alentejano e Costa Vicentina, 2000-2006. Instituto de Conservação da Natureza.

INE, 2013. Estatísticas Da Pesca 2012. Instituto Nacional de Estatística, I.P.

INE, 2019. Estatísticas Da Pesca 2018. Instituto Nacional de Estatística, I.P.

Jacquet, J., Pauly, D., 2008. Funding priorities: big barriers to small-scale fisheries. Conserv. Biol. 22 (4), 832-835.

Jennings, S., Kaiser, M., Reynolds, J.D., 2009. Marine Fisheries Ecology. John Wiley \& Sons.

Kelleher, G., Kenchington, R., 1992. Guidelines for Establishing Marine Protected Areas. A Marine Conservation and Development Report, IUCN, Gland, Switzerland.

Kenchington, R., Bleakley, C., 1994. Identifying priorities for marine protected areas in the insular Pacific. Mar. Pollut. Bull. 29, 3-9.

Lourenço, S., Pereira, J., 2006. Estimating standardised landings per unit effort for an octopus mixed components fishery. Fish. Res. 78, 89-95.

Mullon, C., Freon, P., Cury, P., 2005. The dynamics of collapse in world fisheries. Fish Fish. 6, 111-120. http://dx.doi.org/10.1111/j.1467-2979.2005.00181.x.

Murawski, S.A., Brown, R., Lai, H.L., Rago, P.J., Hendrickson, L., 2000. Large-scale closed areas as a fishery-management tool in temperate marine systems: the Georges Bank experience. Bull. Mar. Sci. 66, 775-798.

Murray, S.N., Ambrose, R.F., Bohnsack, J.A., 1999. No-take reserve networks: sustaining fishery populations and marine ecosystems. Fisheries 24, 11-25.

Muus, B.J., Nielsen, J.G., Dahlstrøm, P., Nyström, B.O., 1999. Sea Fish. ScandInavian Fishing Year Book. Wiley-Blackwell, Hedehusene.

Nilson, J.A., Fulton, E.A., Johnson, C.R., Haward, M., 2019. How to sustain Fisheries: Expert knowledge from 34 nations. Water 11, 213. http://dx.doi. org/10.3390/w11020213.

Pauly, D., Christensen, V., Guenette, S., Pitcher, T.J., Sumaila, U.R., Walters, C.J., Watson, R., Zeller, D., 2002. Towards sustainability in world fisheries. Nature 418, 689-695.
Pereira, T.J., Manique, J., Quintella, B.R., Castro, N., Almeida, P.R., Costa, J.L., 2017a. Changes in trophic ecology of fish assemblages after no take Marine Protected Area designation in the southwestern coast of Portugal. Ocean Coast. Manag. 137, 144-153.

Pereira, T.J., Manique, J., Quintella, B.R., Castro, N., Almeida, P.R., Costa, J.L., 2017b. Changes in fish assemblage structure after implementation of Marine Protected Areas in the south western coast of Portugal. Ocean Coast. Manag. 135, 103-112.

Pereira, T.J., Silva, A.F., Almeida, P.R., Belo, A.F., Costa, J.L., Castro, N., Quintella, B.R., 2017c. Assessing the size adequacy of a small no-take marine protected area (MPA) for Mediterranean moray and European conger. Mar. Ecol. Prog. Ser. 584, 213-227.

Pickett, G.D., Pawson, M.G., 1994. Sea Bass: Biology, Exploitation and Conservation. Chapman \& Hall, London.

Pinnegar, J.K., Engelhard, G.H., Jones, M.C., Cheung, W.W.L, Peck, M.A., Rijnsdorp, A.D., Brander, K.M., 2016. Socio-economic impacts-Fisheries. In: Quante, M., Colijn, F. (Eds.), North Sea Region Climate Change Assessment. In: Regional Climate Studies, Springer, Cham, http://dx.doi.org/10.1007/9783-319-39745-0_12.

Pita, P., Freire, J., 2011. Movements of three large coastal predatory fishes in the northeast Atlantic: a preliminary telemetry study. Sci. Mar. 75, 759-770.

Pita, C., Gaspar, M., 2020. Small-scale Fisheries in Portugal: Current situation, challenges and opportunities for the future. In: Pascual-Fernández, J., Pita, C., Bavinck, M. (Eds.), Small-Scale Fisheries in Europe: Status, Resilience and Governance. In: MARE Publication Series, vol. 23, Springer, Cham, http: //dx.doi.org/10.1007/978-3-030-37371-9_14.

Prista, N., Jones, C.M., Costa, J.L., Costa, M.J., 2008. Inferring Fish Movements from Small-Scale Fisheries Data: The Case of Argyrosomus Regius (Sciaenidae) in Portugal. ICES CM 2008/K-19, Copenhagen, Denmark, p. 19.

Quéro, J.C., Vayne, J.J., 1987. Le maigre, Argyrosomus regius (Asso, 1801) (Pisces, Perciformes, Sciaenidae) du Golfe de Gascogne et des eaux plus septentrionales. Rev. Trav. Inst. Pêches Marit. 49, 35-66.

Roberts, C.M., Bohnsack, J.A., Gell, F., Hawkins, J.P., Goodridge, R., 2001. Effects of marine reserves on adjacent fisheries. Science 294, 1920-1923.

Roberts, C.M., Polunin, N.V.C., 1991. Are marine reserves effective in management of reef fisheries? Rev. Fish Biol. Fish. 1, 65-91.

Roper, C.F.E., Sweeney, M.J., Nauen, C.E., 1984. FAO species catalogue. 3. Cephalopods of the world. An annotated and illustrated catalogue of species of interest to fisheries. FAO Fish. Synopsis 3, 125.

Sainsbury, J.C., 1986. Commercial Fishing Methods: An Introduction to Vessels and Gears, second ed. Fishing News Books Ltd. Smith, Franham - Surrey England.

Sayce, K., Shuman, C., Connor, D., Reisewitz, A., Pope, E., Miller-Henson, M., Poncelet, E., Monié, D., Owens, B., 2013. Beyond traditional stakeholder engagement: Public participation roles in California's statewide marine protected area planning process. Ocean Coast. Manag. 74, 57-66. http://dx. doi.org/10.1016/j.ocecoaman.2012.06.012.

Shester, G.G., Micheli, F., 2011. Conservation challenges for small-scale fisheries: Bycatch and habitat impacts of traps and gillnets. Biol. Cons. 144 (5), 1673-1681.

Silva, J., 2015. Alterações na composição e na estrutura trófica das comunidades de peixes das Áreas Marinhas Protegidas da Ilha do Pessegueiro e Cabo Sardão após a proibição da Pesca (MSc dissertation). Faculty of Sciences, University of Lisbon, Lisbon.

Smith, D.G., 1990. Congridae. In: Quero, J.C., Hureau, J.C., Karrer, C., Post, A., Saldanha, L. (Eds.), Check-List of the Fishes of the Eastern Tropical Atlantic, Vol. 1. CLOFETA, JNICT, SEI, UNESCO, Lisbon, Paris, pp. 156-167.

Sumaila, U.R., Guenette, S., Adler, J., Chuenpagdee, R., 2000. Addressing ecosystem effects of fishing using marine protected areas. ICES J. Mar. Sci. 57, 752-760.

Vaz, M.T.N., 2008. The Portuguese Agriculture and Fisheries at the Start of the Millennium: Is there a way out? Opt. Médit. 383-405.

Viegas, V., 2013. Pesca comercial na costa alentejana: rendimento, esforço de pesca, rejeições e efeitos da proteção (MSc dissertation). University of Évora, Évora.

de Vivero, J.L.S., 2007. The European vision for oceans and seas-Social and political dimensions of the Green Paper on Maritime Policy for the EU. Mar. Policy 31 (4), 409-414.

Voorberg, W., Van der Veer, R., 2020. Co-management as a successful strategy for marine conservation. J. Mar. Sci. Eng. 8, 491. http://dx.doi.org/10.3390/ jmse8070491.

Whitehead, P.J., Bauchot, M.L., Hureau, J.C., Nielsen, J., Tortonese, E. (Eds.), 1989. Fishes of the North-East Atlantic and the Mediterranean, Vols. I, II and III. UNESCO, Paris, p. 1473. 